\title{
Behaviour of culinary tourists: A segmentation study of diners at top-level restaurants
}

\author{
Natalia Daries (D), Eduard Cristobal-Fransi (D), Berta Ferrer-Rosell(D), \\ Estela Marine-Roig (iD \\ Universidad de Lleida (Spain) \\ ndaries@aegern.udl.cat,ecristoba@@aegern.udl.cat,berta.ferrer@aegern.udl.cat,estela.marine@aegern.udl.cat
}

Received June, 2017

Accepted February, 2018

\section{Abstract}

Purpose: The main aim of this research is to characterize the tourists visiting top-level restaurants to ascertain the profile of this type of customer, their behaviour and their influence on the destinations where they are located.

Design/methodology: During the months of July to December 2016, a survey was conducted on a sample of 187 tourists who had visited Michelin-starred restaurants in order to highlight the most valued aspects during the process of choosing, consulting and booking the top-level restaurant service.

Findings The results reveal the existence of two segments whose behaviour is different, where the individuals of the first consider the culinary experience as the main reason for their tourist visit to the destination. In contrast, the second segment considers that their visit to the destination is the main reason for their tourism. Moreover, the diners from both segments display different behaviour in terms of their post-purchase, recommendation and intention to return behaviour and the perception of the status with which their visit to the restaurant provides them.

Research limitations/implications: The main limitation of this research is the fact that only the responses of tourists who have visited top-level restaurants in Spain have been studied

Practical implications: The results of this study may help both the managers of restaurants of a certain level and the public authorities responsible for tourism to make decisions, since these types of restaurants are becoming tourist resources of the first order.

Social implications: Knowledge of the diner could facilitate the optimal management of the restaurant and help orient it as a tourist resource. In certain areas such a resource can become a pole of tourist attraction and contribute towards territorial balance thanks to the positive externalities it generates in the territory where such establishments are located.

Originality/value: the present research focuses on the study of the behaviour of the culinary tourist in an increasingly popular type of tourism with high added value. Culinary tourism is also enormously important in the economy of the destination and for territorial development. Therefore, this work may be of interest both for public authorities and the managers of this type of restaurant, and to create synergies between the two. This work comes to fill a gap in the literature of segmentation in the restoration, since there are few researches that focus on segmentation according to consumer's motivations and perceptions, and none focus on its relationship to tourism at the destination. 
Keywords: Gastronomy, Michelin Guide, Cluster analysis, Gastronomic experience, Motivation behind trip

Jel Codes: D12, Z32, Z33

\section{Introduction}

The restaurant industry has undergone a huge boom in the last decade and is considered an important component of the tourism system (Delgado, Vargas, Montes \& Rodriguez-Torres, 2016); it is considered "one of the most long-standing and traditional sectors of most economies" (Daries-Ramon, Cristobal-Fransi \& MarineRoig, 2017). However, the saturation of certain types of catering, as well as the emergence of new culinary techniques together with technological advances, the internationalization of the sector and changes in the habits and tastes of consumers, has led to a notable growth of the restaurant industry of a certain level. The UNWTO (2017) report on gastronomy tourism pointed out that the weight of gastronomy in destinations' tourism revenue was more than $30 \%$ and that this margin would tend to grow and considers gastronomy to be a distinctive element of destination. In 2016, for example, the restaurant industry turned over 35,131 million euros in Spain, and every citizen consumed (lunched or had dinner) out an average of 157 times (The NPD Group, 2017). This sector employed 1.6 million in Spain in 2016, according to the active population survey (Encuesta de Población Activa - EPA) published by the National Statistics Institute - INE (2017).

In this context, attracting culinary tourists has become the goal of many destinations since they tend to stay longer at the destination, increase tourist spending on local products, and, ultimately, create greater sustainability (UNWTO, 2017). Food and wine have been found to be fundamental attraction factors of a destination and the element of their image which is most evenly recognised across different types of destinations (Marine-Roig \& Anton Clavé, 2016). The reasons why travellers choose one or another destination are different, but new tourism trends indicate that quality cuisine is becoming increasingly relevant in the process of choosing a destination and the construction of the destination image (Lai, Khoo-Lattimore \& Wang, 2017). The increased competitiveness in the catering industry has led to the development of strategies that require segmentation to respond to an increasingly plural and heterogeneous demand consisting of customers seeking not only to satiate their appetite but enjoy the experience (Thompson \& Prideaux, 2009; Yang \& Mattila, 2017).

Today's customer is far more informed, demanding and often, plans and books their holidays and leisure time, with totally different interests and who, in accordance with increasing purchasing power, they demand more specific, more personalized products, even if this entails a higher economic cost (Goolaup, Solér \& Nunkoo, 2017; Yang \& Mattila, 2017). The gastronomic tourist, specifically, values cuisine as a means of socializing and exchanging experiences, is increasingly demanding, and has higher spending power than the average tourist (UNWTO, 2017). The UNWTO study reveals that the traditional strategies in the development of gastronomy tourism must evolve into strategic tools to articulate the quality, variety and uniqueness of local products and gastronomy of a territory. Hence, knowing the weight of the factors that have motivated the choice of restaurant or the relevance that the restaurant has in the choice of destination, together with information about the characteristics and behaviour of customers is fundamental, and companies are starting to become aware of the importance of diversifying the supply and segmenting the market (Kline, Greenwood \& Joyner., 2015; Levitt, Zhang, DiPietro \& Meng, 2017). Moreover, there has still been very little research on high-quality restaurants in spite of the economic and tourist importance they may have (Daries-Ramon, Cristobal-Fransi, Ferrer-Rosell \& Marine-Roig, 2018).

Therefore, the main aim of this research is to characterize the tourists visiting top-level restaurants to ascertain the profile of this type of customer, their behaviour and their influence on the destinations where they are located. To achieve this aim, the work is structured into two parts. The first part consists of a literature review of the segmentation of markets in the restaurant industry and the factors that influence tourists' culinary behaviour. The second part, through an empirical study, performs a segmentation analysis to identify the different groups of tourists who go to top-level restaurants at the tourism destination. 


\section{The segmentation of markets in the restaurant industry}

The preliminary step to determining a profitable target market to subsequently implement an appropriate positioning strategy is the classification of, Tseng \& Lin, 2017). Furthermore, tourism managers highlight the importance of understanding tourists' motivations for prospective customers segmenting a major market into different groups that may require different marketing strategies (Kotler, Bowen \& Makens, 2014). This process is known as market segmentation and it allows a company to identify key consumer groups and adapt marketing strategies to their needs (Bruwer \& Li, 2007).

If we focus on the tourism industry, we will find great diversity in tourists' behaviour and a major evolution in their motivations when choosing, such as the pursuit of unique experiences, the influence of environmental aspects, flexibility of service, innovation, or the search for quality products (Carballo, Fraiz, Araújo \& Rivo, 2016). Specifically, the gastronomic tourist has been found to spend more than average, be demanding and seek new experiences and trends, and is interested to discover the authenticity of destinations through their food (UNWTO, 2017). This makes tourism market segmentation an especially relevant line of work to marketing, both in the field of academia and in business management. Thus, thanks to this segmentation a more efficient allocation of resources is possible, selecting the strategically most important groups and determining the most suitable product, price, distribution and communication policies (Cho Bonn \& Brymer, 2017; Lee, Jan, Tseng \& Lin, 2018) affecting their decisions about holiday destinations. By categorizing tourists into different segments, tourism managers will be able to develop products and services that effectively appeal to each group (Srihadi, Sukandar \& Soehadi, 2016).

In the field of gastronomy, segmentation has been acknowledged as being a useful tool to facilitate the development of strategies for the marketing of this tourism service (Seongseop, Choe \& Lee, 2016). To segment restaurant customers, previous studies have used socio-demographic variables (e.g., gender, income, nationality) and socio-psychological variables (e.g., value, lifestyle, personality). The socio-demographic characteristics used include gender, education, income, or age (Batra, 2008; Honkanen, 2010; Hwang, Han \& Kim, 2015; Kim, Ng \& Kim, 2009).

In terms of level of education and income, in a study on ethnic restaurants, Roseman (2006) identified that respondents with a higher level of education and income were more likely to choose this type of restaurants than their less-educated and less-well-paid counterparts. Barber and Scarcelli (2010) classified customers by gender and education to identify the effect on customers' evaluation of the cleanliness of a restaurant. The women diners were more sensitive to cleanliness in the restaurant environment than their male counterparts. Continuing along these lines, in the study by Hwang et al. (2015), women were more likely to express their opinions or emotions with regard to the quality of the service of a restaurant than men. Other research has revealed that the overall degree of satisfaction differs according to age (Kim, $\mathrm{Ng} \& \mathrm{Kim}, 2009)$. In this sense, the results showed that older customers were more satisfied than younger customers, as they tended to be more loyal due to a higher frequency of visits (Kim, $\mathrm{Ng} \& \mathrm{Kim}, 2009)$.

On the other hand, we can find a series of research studies that address segmentation using socio-psychological variables such as lifestyle, values or personality traits. Various studies have used lifestyle as a segmentation variable (Bruwer \& Li, 2007, Choe \& Cho, 2011; Jang, Kim \& Bonn, 2011; Wycherleya, McCarthy \& Cowan, 2008). The work of Wycherleya et al. (2008) used a scale of food-related lifestyles and identified six categories of consumers: "adventurers", "rational", "sloppy", "likes a snack", "conservative", and "not involved". In their study, the members of the "adventurous" and "rational" groups revealed a higher level of preference for speciality food products. Other research has sought to identify the characteristics of customers to restaurants according to their reasons for preferring a certain type of food or the benefits sought (John and Horsefall, 2012; Roseman, 2006; Tan and Lo, 2008). Damian and Suárez-Barraza (2015) indicate that these segmentation tasks enable finding out consumer behaviour and implementing process innovation in tourism management.

In short, we can find several pieces of research that have segmented restaurant diners according to sociodemographic or socio-psychological variables in order to obtain customer profiles or characteristics. However, 
no work has been found that focuses on the segmentation of diners in top-level restaurants according to their motivations and perceptions, despite this sector of the industry growing rapidly. In fact, as the dishes prepared in this type of restaurant usually differ from those that are consumed in everyday life, customers might have certain reasons to visit a particular high-level restaurant. Therefore, finding out the reasons that lead to the decision by customers to frequent this type of restaurant may provide managers with relevant information to be able to determine the most appropriate target market and to develop customized marketing strategies. In addition, no studies were found on restaurant customer segmentation that take into account the tourism component and analyse the customer's relationship with the destination and the restaurant, and their relative importance.

\section{Factors influencing tourists' gastronomic behaviour}

The proper identification of the different needs of the different tourist segments eases a better design of a restaurant's range of cuisine (Sengel, Karagoz, Cetin, Dincer, Ertugral \& Balık., 2015). Despite its importance, the study of the different characteristics of tourists and their perception of the service offered by a restaurant has scarcely been discussed in the literature.

It is clear that when choosing a restaurant, the type of food is crucial. Authors like Giesen, Havermans, Douven, Tekelenburg and Jansen (2010) claim that studies on the choice of the type of food focus on the understanding of the determinants of behaviours related to foods, including the taste, preferences, the choice and its actual ingestion. The taste for food they call "palatability or the pleasure obtained when tasting a certain food". Following this line, Duarte, O'neill, Liu and O'shea (2013) similarly found that quality and taste are the main factors affecting the selection of restaurants, although previous positive experience, a clean working environment and attentive service are additional factors that greatly influence.

Regarding the consumption of food by the tourist, Mak, Lumbers, Eves and Chang (2012) state that it depends on five factors: 1) Cultural and religious factors; 2) Socio-demographic factors; 3) Motivational factors; 4) Personality; and 5) Previous experience. On the other hand, Kim, Eves and Scarles (2009) propose a model of consumption that contains three main factors divided, in turn, into several subfactors: Motivational factors; demographic factors and physiological factors. We can therefore see that there is an extensivevariety of food attributes that could be contemplated when analysing tourists' behaviour when choosing a restaurant.

The present work focuses on the choice of top-level restaurants, the characteristics of the diner and their preferences. To do so, we will focus on demographic and motivational factors.

\subsection{Demographic factors}

Demographic factors have been widely studied and accepted as important aspects that affect tourists' selection of restaurant and type of food. These include indicators such as age, gender, level of education, marital status, religious beliefs, etc. (Cho et al., 2017; Kim, Lee \& Klenosky, 2013). Demographic factors are important for food consumption and choice of establishment (Duncan, Josiam, Kim \& Kalldin., 2015). In fact, the results of different studies suggested that age, gender, and social status are significant factors in determining culinary preferences (Furst, Connors, Bisogni, Bobal \& Falk, 1996; Srivastava, 2015).

Kivela and Crotts (2005) suggest that tourists have different approaches to the culinary experience depending on their origin. For example, it has been found that individuals from Eastern cultures avoid restaurants serving local food, but those from Western cultures are more interested in trying foods that are unfamiliar to them (Tse \& Crotts, 2005). In addition, it is stated that people with higher purchasing power and a higher level of education are more interested in local gastronomy, as they not only consume food to satisfy a physical need, but also value discovering new dishes and associating food with the local culture (Wadolowska, Babicz-Zelinska \& Czarnocinska, 2008). In the same line, authors as López-Guzmán and Sánchez-Cañizares (2012), Pérez-Gálvez, López-Guzmán, Buiza and Medina-Viruel (2017) or Tsai (2016) indicated that age and educational level of the tourists are relevant when they decide the gastronomic offer. 


\subsection{Motivational factors}

Several studies have found that motivational factors influence tourists' gastronomic behaviour and that local food plays a major role in the overall satisfaction of a trip (Cetin \& Bilgihan, 2016). Fields (2002) poses four motivational factors that influence in the tourist's choice of restaurant: physical, cultural, interpersonal and status factors. However, Kim, Eves and Scarles (2009) present nine subfactors that explain the motivational factor: exciting experience; escape from routine; concern for health; discovering new things; authentic experience; fellowship; prestige; sensorial and physical attraction in their model of gastronomic consumption. Gastronomic motivation in tourism has been classified into two main categories: the symbolic dimension (learning about local culture, exciting experience, authenticity, prestige), and compulsory dimension (concern for health, physical need, etc.) (Mak et al., 2012). Tasting local gastronomy is considered to be a pleasant and exciting activity (Kivela \& Crotts, 2006).Using this type of factors, Björk and Kauppinen-Räisänen (2016) develop a research focused in local food market that reveals three types of food-related behaviour:

- Experiencers, that consider food as essential to destination selection.

- Enjoyers, that have positive attitudes towards food; and

- Survivors, that consider that local food of their destination covers physiological needs.

Eating is a basic human necessity. Every tourist looks for the gastronomy of the destination when travelling far from home. In addition to the category of the restaurant, its decoration, music, lighting and architecture are accepted as elements of the physical environment (Yuksel \& Yuksel, 2003). Travelling is considered as a way of escaping from routine (Smith, 1994), so tourists prefer to eat at authentic and special places rather than in restaurants belonging to international chains (Sengel et al., 2015).

\section{Methodology}

The methodology followed to achieve the goals was an empirical study on a sample of tourists who have visited restaurants with a Michelin star in the last two years, on whom a survey was conducted in order to elucidate the most valued aspects in the process of choosing, consulting and booking a top-level restaurant service.

Data collection was carried out during the months of July to December 2016 using self-administered questionnaires via the Internet. Structured self-administered questionnaires were preferred since they present a higher response rate and the researcher's influence is minimized (Lietz, 2010; Oppenheim, 1992). The link to the questionnaire was administered through the Facebook profiles of gastronomy and travel bloggers with a high number of followers: Webosfritos (96,918); Garbancita (11,798); Gastronomias del Mundo (13,642), among others. The numbers of followers correspond to July 2016.

Following Leiper (1990), the drafting of the questionnaire was based on tourist attraction systems, structuring the survey around different aspects such as the tourist's profile or motivations, on the one hand; and as ratings of the destination, the restaurant or surrounding elements, on the other. Also taken into account were the works by Kim, Park, Kim \& Ryu (2013), Kukanja, Omerzel and Kodrič (2016), Yuksel, Yuksel and Bilim (2010), for questions about the global assessment, satisfaction and loyalty, both to the restaurant and to the destination.

A total of 432 responses were obtained, but the respondents who had spent the night away from their place of residence when going to a Michelin-starred restaurant were selected, following the guidelines established by the World Tourism Organization (UNWTO, 1988), which defines the tourist as "the temporary visitor who remains at least 24 hours at the place of destination, other than the usual environment", to ensure the assessment of the destination. Finally, there was a total of 187 valid answers, from respondents who we considered tourists. According to Manfreda, Bosnjak, Berzelak, Haas, Vehovar and Berzelak (2008) the sample size is sufficient to draw robust conclusions. Manfreda et al. (2008) compare the samples used in 45 studies based on questionnaires managed via the web. The dispersion of sizes used varies from a minimum of 28 to a maximum of 2,979, with a mode of 115 responses. It should be noted that to stimulate responding, a gift was offered to clients who 
answered the questionnaire; this incentive consisted of a meal for two in a Michelin-starred restaurant of their choice.

The respondent profile is as follows: female (61\%), middle-aged (42\% are between 35 and 44 years old), with university studies $(88.8 \%)$, who goes with a partner to a top-level restaurant $(62.6 \%)$ spending one or two nights at the destination $(67.4 \%)$.

In order to distribute the respondents -customers of a restaurant with Michelin star(s)- into homogeneous segments, an analysis of $\mathrm{K}$-mean conglomerates was carried out, as it is one of the most common and is used for large samples (Dolnicar, 2002; Everitt, Landau, Leese \& Stahl, 2011; Tuma, Decker \& Scholz, 2011).

To do so, the questions of the questionnaire for which a rating was required (score of 1 to 5) on the questions related with gastronomy, the personal attributes that influence visiting a restaurant and the attributes related with the establishment were considered active (or segment-based) variables (see Table 2).

The first step was to perform a hierarchical analysis in order to naturally obtain the number of groups (two groups). Then, the K-mean conglomerates were carried out, forcing the extraction of two segments. As a result, therefore, two segments of different sizes were obtained: a first group of 52 individuals, and a second, larger segment of 135 people.

The centres of the two final conglomerates obtained present a figure of 4.87 out of 5 for the first segment and 4.56 for the second. These values show a high evaluation of satisfaction with the gastronomic experience in the restaurant in both groups. In turn, ANOVA analysis of the clusters was performed to see if the resulting segments are different. The analysis reinforces the results obtained giving Snedecor's F a value of 5.607 with a significance of 0.019 .

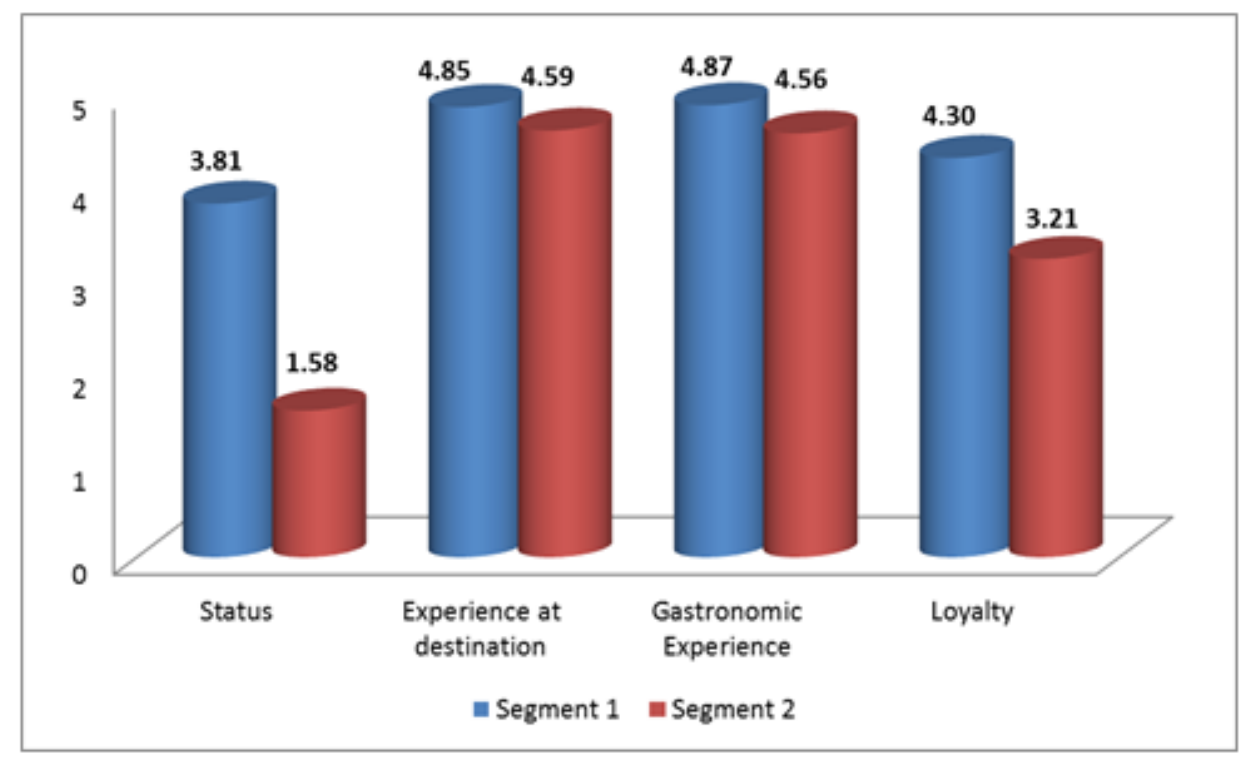

Figure 1. Mean scores by segments

Initial non-parametric analysis allows detecting behavioural differences between the two groups. Indeed, Wilcoxon-Mann-Whitney analysis (assuming that the variables do not follow a normal distribution), grouping according to the two segments found, shows significant differences at the 0.05 level of significance in terms of status, experience at the destination, the gastronomic experience and loyalty (see Table 1). All analyses were performed using SPSS version 20 software. 


\begin{tabular}{|l|c|c|c|c|}
\cline { 2 - 5 } \multicolumn{1}{c|}{} & Status & $\begin{array}{c}\text { Experience at } \\
\text { destination }\end{array}$ & $\begin{array}{c}\text { Dining } \\
\text { experience }\end{array}$ & Loyalty \\
\hline Mann-Whitney U Test & 936.500 & 2845.000 & 3023.500 & 1973.500 \\
\hline Wilcoxon w & 10116.500 & 11756.000 & 12203.500 & 10751.500 \\
\hline Z & -8.284 & -2.447 & -2.014 & -4.365 \\
\hline Asymp. sig. (bilateral) & $.000\left(^{*}\right)$ & $.014\left(^{*}\right)$ & $.044\left(^{*}\right)$ & $.000\left(^{*}\right)$ \\
\hline
\end{tabular}

$\mathrm{C}\left({ }^{*}\right)$ Significant differences in means at the 0.05 level of significance

Table 1. Wilcoxon-Mann Whitney test of comparison of means among segments

\section{Results}

Both segments rate very positively the experience perceived both at the destination and in the restaurant with scores above 4, the first segment presenting the highest scores. The biggest differences are perceived for the personal attribution of status as an influencing element when choosing a restaurant and for loyalty. Figure 1 shows the mean scores obtained. The scale ranges between 1 and 5 . Different behaviour is observed depending on the segment concerned.

\begin{tabular}{|c|c|c|c|}
\hline & Segment 1 & Segment 2 & Total \\
\hline Learning about gastronomy and cuisine & 4.77 & 3.78 & 4.05 \\
\hline The taste for wine & 4.29 & 3.17 & 3.48 \\
\hline Trying new textures, flavours and different dishes & 4.83 & 4.59 & 4.65 \\
\hline Discovering new forms of preparation, cooking, presentation, etc. & 4.83 & 4.45 & 4.56 \\
\hline The quality of the ingredients used to make the dishes & 4.85 & 4.46 & 4.57 \\
\hline Discovering the products of the local area & 4.60 & 3.83 & 4.04 \\
\hline The status it gives me & 3.81 & 1.58 & 2.20 \\
\hline Visiting Michelin-starred restaurants helps me to be accepted by other people & 3.48 & 1.17 & 1.81 \\
\hline Enjoying meeting the chef & 4.60 & 2.80 & 3.30 \\
\hline Visiting Michelin-starred restaurants impresses people & 3.85 & 1.42 & 2.10 \\
\hline Being able to tell my family and friends about it afterwards & 4.10 & 1.69 & 2.36 \\
\hline Relaxing and unwinding & 4.65 & 3.64 & 3.93 \\
\hline I was given it as a gift & 4.60 & 2.93 & 3.39 \\
\hline It makes me happy & 4.83 & 4.30 & 4.45 \\
\hline The good experiences at Michelin restaurants linger in my memory for a long time & 4.90 & 4.07 & 4.30 \\
\hline I like to eat well and I often frequent Michelin-starred restaurants & 4.38 & 3.30 & 3.60 \\
\hline Decoration of the establishment & 4.73 & 3.85 & 4.10 \\
\hline The meticulous service provided at this type of restaurant & 4.88 & 4.16 & 4.36 \\
\hline The chance to visit the facilities, kitchen, cellar, etc. & 4.88 & 3.13 & 3.61 \\
\hline Customer service & 4.96 & 4.14 & 4.37 \\
\hline Location (position, views, etc.) & 4.54 & 3.30 & 3.64 \\
\hline Gourmet shop & 4.17 & 1.87 & 2.51 \\
\hline Parking & 4.33 & 1.85 & 2.54 \\
\hline
\end{tabular}

Table 2. Evaluations of the motivational factors by segments

We now proceed to profile each of segments found, associating them to behavioural and socio-demographic variables. It must be noted that associations between both behavioural and socio-demographic variables with cluster variable are significant at $10 \%(\mathrm{p}$-value $<0.1)$.

\subsection{Characterization of Segment 1}

The individuals in this segment consider the culinary experience at the Michelin-starred restaurant as the main reason for visiting the destination ( $44.2 \%$ versus $19.2 \%$ who state that the destination is the priority). In fact, they were the users who sought the least information about activities and places to visit at the site where the restaurant was located $(71.2 \%$ did not seek information). In addition, the type of activities in which they were interested were related either with gastronomy, such as gastronomic fairs or conferences, or with wine-related activities. It is the group that makes the most purchases at the destination (80.8\%), mostly typical products including food, wine and even fashion or footwear. 
As it can be observed in Table 2, this segment is more interested in gastronomy-related attributes at the destination. The respondents from this segment claim to wish to discover the products of the area (4.60), learn about local cooking and gastronomy (4.77), and show a great interest in wine (4.29).

With regard to their experience at the restaurant, they want to meet the chef (4.60), they pay attention to the decoration of the restaurant (4.73), and greatly value the opportunity to visit the facilities (kitchen, rooms, cellar, etc.) (4.88). They also look for restaurants that are well located (4.54), have parking facilities (4.33), and have a gourmet shop (4.17). It is the group that displays greater predisposition both to recommending (4.82) and returning both to the area (4.54) and the restaurant (4.30).

The members of this group are much more active when it comes to using ICT. They visit the restaurant website, either to confirm their booking $(36.5 \%)$ or to view the social profiles $(26.9 \%)$. They also use social networks to share content about their dining experience, especially photos $(76.9 \%)$, reviews $(44.2 \%)$, or videos $(9.6 \%)$ of the restaurant and the food. Continuing along this line, the customers in this group actively participate in the online reputation of the restaurant, posting positive reviews on one of the social networks (53.7\%) after visiting the restaurant.

In demographic terms, the clientele consists of both men and women ( $49 \%$ and $51 \%$, respectively), slightly mature (43\% older than 45$)$, in employment (90.4\%) and with a medium level of education.

The individuals pertaining to this segment can be labelled: socially active tourists who decisively appreciate cuisine.

\subsection{Characterization of Segment 2}

The second group consists of 135 people. With regard to the appraisal of their experience at the destination and their dining experience, they are in a slightly lower position than segment 1, but the greatest distance is in the aspect of projected image or status as a reason for visiting the restaurant and the aspect of loyalty or intention to return both the destination and to the culinary establishment (see Figure 1).

Unlike the first group, the members of this group consider their visit to the destination as the main reason for their tourist trip $(39.3 \%$ vs. $25.9 \%)$. In fact, they are the ones to seek the least information about the restaurant before booking (28.1\%), and neither did they actively participate on the restaurant website (63.7\%). Likewise, the individuals in this segment are less active in the social networks, connecting, but not sharing content related to their dining experience $(32.6 \%)$. Most did not make appraisals on social networks after visiting the restaurant $(60.3 \%)$.

Of the total respondents, it is the members of this group that are most interested in the different activities that can be pursued at the destination where the restaurant is located (46.7\%). Almost all of the segment $(99.3 \%)$ sought information on the establishment's website about activities to carry out at the destination, followed by the destination's tourist information website (77\%). Although they also show an interest in gastronomic activities $(58.5 \%)$, in contrast to segment 1 , they did activities related to adventure tourism $(8.9 \%)$, ecotourism $(5.9 \%)$ and business tourism $(5.9 \%)$. Visits to family and friends are noteworthy $(20.7 \%)$. Like the first group, they shopped at the destination, although to a lesser extent (60.7\%), above all purchasing typical food products $(41.5 \%)$.

The individuals in this group are less interested in attributes related to gastronomy in all aspects in general (see Table 2). Concerning their experience at the restaurant, what they value most highly is the service (4.16) and the attention to the customer (4.14) provided by this type of top-level restaurants. However, aspects such as the restaurant having a gourmet shop (1.87) or parking facilities are practically not taken into account (1.85).

Unlike segment 2, in this case they do not consider that the visit to a Michelin-starred restaurant could provide them with higher status, or be accepted by other people. They are not impressed by the fact of going to such establishments and therefore they do not give so much importance to sharing the experience and telling family and friends about it. They do claim, however, that "it makes them happy" to go to a Michelin-starred restaurant, but on a personal level (4.30). 
Regarding the demographic profile, we are talking about a clientele principally consisting of women (65.4\%), who are fairly young $(66.1 \%$ under 44 years of age), employed $(88.1 \%)$, and with some degree of higher education $(85.7 \%)$.

The individuals pertaining to this segment can be labelled: female travellers who value gastronomy as another resource that the destination has to offer.

\section{Discussion}

The aim of the present study was to profile the tourists visiting top-level restaurants in order to find out about their behaviour, their influence on the tourism destination, and what type of consumers they are. So, first of all, we can say that we have discovered two different segments of tourist. The first group of tourists,, for whom the visit to a top-level restaurant is the main reason to go to the destination; and a second group of tourists, who visit the destination anyway. We can also add that both groups value satisfactorily both their experience at the destination and their gastronomic experience. These aspects, in both segments, have scored over 4.5 on a scale of 1 to 5 , where 3 is the central value. However, we find remarkable differences between the two segments in status and loyalty factors.

Nevertheless, we must not content ourselves with these results. In view of the data, and in reference to segment 1 , we can posit that the online management of a restaurant, especially a top-level one, carried out as if it were just another extension of a traditional establishment, may be an important reason for marketing failures. Any digital marketing initiative, including e-commerce, must adapt to the characteristics of this new medium and to its users, and segment 1 is highly active on the Internet.

We can draw a series of insights from the results obtained:

Individuals in the two segments found, display different behaviour in terms of the status they perceive by visiting a top-level restaurant and concerning their post-purchase, recommendation and intention to return behaviour. These results are in line with Bakhshi, Kanuparthy and Gilbert (2014) and DiPietro, Crews, Gustafson and Strick (2012).

Some of the aspects that are most valued by culinary tourists are related to the possibility of trying new gastronomic proposals, getting to know the local produce and products and learning innovations concerning gastronomy and cuisine (Hall \& Gössling, 2013).

Other aspects that customers highlight are customer service, the excellent service provided by this type of establishment, and even the possibility of visiting the facilities such as the kitchen, cellar, etc. (Sánchez-Cañizares \& López-Guzmán, 2012).

The overall experience is especially valued, as it is considered to persist in time, and ultimately it makes them "happy". This greatly influences the attitude, especially in the first segment, of being able to relate their experience to friends and family (Chang, Kivela, \& Mak, 2011).

Focusing on the segments' behaviour, it is precisely the youngest customers (the second segment in our study) that are most demanding and require higher quality service. At the same time it is the segment with the greatest weight. They are also the tourists who consider their visit to the destination as being the main reason for their trip. In contrast, the members of the first segment consider the culinary experience as the main consideration around which to plan their trip. They find information before travelling to the destination and they are far more active in the use of the new technologies. These results are in line with the segmentation studies performed using various types of factors to define the behaviour and the attitude of the diner (Björk \& Kauppinen-Räisänen, 2016; Pérez-Gálvez et al., 2017; Wall \& Berry, 2007). 


\section{Conclusions}

The growing heterogeneity existing in the preferences of tourists makes it necessary to deepen the knowledge of the factors that can influence their behavior and decision processes. Nevertheless, knowing consumers is not an easy task. This fact justifies the high number of researches carried out from different areas that have had consumer behavior as the scope of application.

If we look at the existing literature on segmentation studies in the field of e-tourism, we can frame this research within the works that integrate variables of a different nature, to be able to offer more complete and global results, and make the segments accessible, substantive and usable (Kotler, 1997). Segmentation analysis was based on the experience of the tourist both at the destination and at the restaurant itself, as well as on personal attributes like status; and loyalty to such services. Having found the segments, they were characterized on the basis of socio-demographic variables, online behaviour both when seeking information and sharing it, attitudinal and motivational variables. We can see that the main variables that, according to our research, determine the decision to go to a restaurant are related with both the quality of the product on offer, the variety and originality of the menu, as well as the quality of the service provided and the experiences perceived, as detailed below.

The kinds of behaviour described in this research around the two segments, mean that the managers of restaurants of a certain category must be especially attentive to maintain and improve their quality standards to retain these clients. Over time these clients will migrate towards a more experiential and more loyal type of behaviour (the behaviour of the first segment). The investment made in their quality system should lead to a migration of customers from the second segment to the first.

The recommended strategy proposed in this case is therefore to satisfy the requirements of the second segment to retain them and at the same time attract other tourists with this same profile. In this way, with the passage of time these customers may migrate to the first segment, whose members are more likely to revisit the establishment and therefore ensure a continued business volume. Likewise, for the managers of tourist destinations, it should be paramount to include top-level gastronomy as a significant tourism resource. And, on the other hand, these establishments should be encouraged to focus more on tourism and to incorporate tourism resources of the area as a further attraction and incentive to go to the restaurant, thus creating positive synergies between the destination, its management organizations and the restaurants to create a mutual understanding and benefit. In this way, and although up-scale culinary tourism is a pursuit of a minority of tourists, its full potential could be exploited both in terms of the high level of spending it represents in high quality products and in improving the perception of the destination and its sustainability (UNWTO, 2017).

To conclude this section, we would highlight the main limitations and possible lines of future research arising from this study. Its main limitation is the fact that only the responses of tourists who have visited top-level restaurants in Spain have been studied. It would be interesting for future work to extend the field of study to establishments in other countries which would in turn provide a larger number of responses, thus ensuring a higher degree of validity of the results. It would also help us analyse the influence and the role that the culture and characteristics of the country may have on the process of market segmentation.

We would also add that a future line of research would be to work on theoretical aspects related to results of this work. That is, studying the factors that lead diners at this type of restaurants to become more active or more social and their relation with the destination. Also, the factors that may motivate the passage from one segment to another should be studied. Another possible line of research would be to conduct a longitudinal study with the same variables used for this research to analyse the evolution and trends of tourists in terms of their consumption behaviour and choice of restaurant. Finally, it would be interesting to deepen the creation of specific scales or studies for the analysis of the image of gastronomy and its components and how it can influence the choice of destination for each type of segment. 


\section{Declaration of Conflicting Interests}

The authors declared no potential conflicts of interest with respect to the research, authorship, and/or publication of this article.

\section{Funding}

The authors acknowledge the support of the Catalan Government for the accreditation as Consolidated Research Group TURESCO (2017 SGR 49). Authors also acknowledge the University of Lleida grant 2017TR265 and the INDEST grants for research projects (2017 call). This work was supported by the Spanish Ministry of Economy, Industry and Competitiveness [Grant id.: TURCOLAB ECO2017-88984-R]. Finally, a grant was also received from the UdL Language Institute (2017 call) for editing services.

\section{References}

Bakhshi, S., Kanuparthy, P., \& Gilbert, E. (2014). Demographics, weather and online reviews: A study of restaurant recommendations. In Proceedings of the 23rd international conference on World wide web (pp. 443-454). ACM. https://doi.org/10.1145/2566486.2568021

Barber, N. \& Scarcelli, J. (2010). Enhancing the assessment of tangible service quality through the creation of a cleanliness measurement scale. Measuring Service Quality, 20(1), 46-69.

https://doi.org/10.1108/09604521011011630

Batra, A. (2008). Foreign tourists' motivation and information source(s) influencing their preference for eating out at ethnic restaurants in Bangkok. International Journal of Hospitality Tourism Administration, 9(1), 1-17. https://doi.org/10.1080/15256480801910178

Björk, P., \& Kauppinen-Räisänen, H. (2016). Local food: A source for destination attraction. International Journal of Contemporary Hospitality Management, 28(1), 177-194. https://doi.org/10.1108/IJCHM-05-2014-0214

Bruwer, J., \& Li, E. (2007). Wine-related lifestyle (WRL) market segmentation: Demographic and behavioural factors. Journal of Wine Research, 18(1), 19-34. https://doi.org/10.1080/09571260701526865

Carballo, R., Fraiz, J.A., Araújo, N., \& Rivo, E. (2016). Segmentación del mercado de un destino turístico de interior. El caso de A Ribeira Sacra (Ourense). PASOS. Revista de Turismo y Patrimonio Cultural, 14(2), 369-383. https://doi.org/10.25145/j.pasos.2016.14.024

Cetin, G., \& Bilgihan, A. (2016). Components of cultural tourists' experiences in destinations. Current Issues in Tourism, 19(2), 137-154. https://doi.org/10.1080/13683500.2014.994595

Chang, R.C., Kivela, J., \& Mak, A.H. (2011). Attributes that influence the evaluation of travel dining experience: When East meets West. Tourism Management, 32(2), 307-316. https://doi.org/10.1016/j.tourman.2010.02.009

Cho, M., Bonn, M.A., \& Brymer, R.A. (2017). A constraint-based approach to wine tourism market segmentation. Journal of Hospitality \& Tourism Research, 41(4), 415-444.

https://doi.org/10.1177/1096348014538049

Choe, J.Y., \& Cho, M.S. (2011). Food neophobia and willingness to try non-traditional foods for Koreans. Food Quality and Preference, 22(7), 671-677. https://doi.org/10.1016/j.foodqual.2011.05.002

Daries-Ramon, N., Cristobal-Fransi, E., \& Marine-Roig, E. (2017). Deployment of restaurants websites' marketing features: The case of Spanish Michelin-starred restaurants. International Journal of Hospitality \& Tourism Administration (Online print). https://doi.org/10.1080/15256480.2017.1383961

Daries, N., Cristobal-Fransi, E., Ferrer-Rosell, B., \& Marine-Roig, E. (2018). Maturity and development of restaurant websites: A comparison of Michelin-starred restaurants in France, Italy and Spain. International Journal of Hospitality Management, 73, 125-137. https://doi.org/10.1016/j.ijhm.2018.02.007

Damian, I.E., \& Suárez-Barraza, M.F. (2015). Innovación de procesos en la gestión turística: Una revisión de la literatura. Intangible Capital, 11(1), 147-165. 
Delgado, A., Vargas, E.E., Montes, J.M., \& Rodriguez-Torres, F. (2016). Innovation in tourism companies, where are they and where are they going? An approach to the state of knowledge. Intangible Capital, 12(4), 1088-1155. https://doi.org/10.3926/ic.778

DiPietro, R.B., Crews, T.B., Gustafson, C., \& Strick, S. (2012). The use of social networking sites in the restaurant industry: Best practices. Journal of Foodservice Business Research, 15(3), 265-284.

https://doi.org/10.1080/15378020.2012.706193

Dolnicar, S. (2002). A review of data-driven market segmentation in tourism. Journal of Travel and Tourism Marketing, 12(1), 1-22. https://doi.org/10.1300/J073v12n01_01

Duarte, A., O'neill, M., Liu, Y.,\& O'shea, M. (2013). Factors driving consumer restaurant choice: An exploratory study from the Southeastern United States. Journal of Hospitality Marketing \& Management, 22(5), 547-567. https://doi.org/10.1080/19368623.2012.671562

Duncan, J.L., Josiam, B.M., Kim, Y.H., \& Kalldin, A.C. (2015). Using factor-cluster analysis to segment patrons of casual dining establishments in the United States. British Food Journal, 117(4), 1377-1398. https://doi.org/10.1108/BFJ-04-2014-0142

Everitt, B.S., Landau, S., Leese, M., \& Stahl, D. (2011). Hierarcbical clustering. Cluster Analysis (5th Edition)(pp. 71110). Hoboken, USA: John Wiley \& Sons Ltd..

Fields, K. (2002). Demand for gastronomy product: motivational factors. In Hjalager, A. Richards, G. (eds.), Tourism and Gastronomy (pp. 37-50). London: Routledge.

Furst, T., Connors, M., Bisogni, C.A., Bobal, J., \& Falk, L.W. (1996). Foodchoice: A conceptual model of the process. Appetite, 26(3), 247-266. https://doi.org/10.1006/appe.1996.0019

Giesen, J.C.A.H., Havermans, R.C., Douven, A., Tekelenburg, M., \& Jansen, A. (2010). Will Work for Snack Food: The association of BMI and Snack Reinforcement. Obesity, 18(5), 966-970.

https://doi.org/10.1038/oby.2010.20

Goolaup, S., Solér, C., \& Nunkoo, R. (2017). Developing a Theory of Surprise from Travelers' Extraordinary Food Experiences. Journal of Travel Research, 57(2), 218-231.

Hall, C.M., \& Gössling, S. (Eds.). (2013). Sustainable culinary systems: Local foods, innovation, and tourism \& hospitality. London, UK: Routledge.

Honkanen, P. (2010). Food preference based segments in Russia. Food Quality and Preference, 21(1), 65-67. https://doi.org/10.1016/j.foodqual.2009.08.005

Hwang, J., Han, H., \& Kim, S. (2015). How can employees engage customers? Application of social penetration theory to the full-service restaurant industry by gender. International Journal of Contemporary Hospitality Management, 27(6), 1117-1134. https://doi.org/10.1108/IJCHM-03-2014-0154

INE (Instituto Nacional de Estadística) (2017). Ocupados por ramas de actividad, por tipo de ocupación, por situación profesional y por tipo de puesto laboral. Available at: http://www.ine.es/ (Accessed: June $\left.4^{\text {th }}, 2017\right)$.

Jang, Y.J., Kim, W.G., \& Bonn, M.A. (2011). Generation Y consumers' selection attributes and behavioral intentions concerning green restaurants. International Journal of Hospitality Management, 30(4), 803-811. https://doi.org/10.1016/j.ijhm.2010.12.012

John, A.G., \& Horsefall, A. (2012). Behavioral-based segmentation and marketing success: An empirical investigation of fast food industry. European Journal of Business and Management, 4(15), 56-65.

Kim, S., Lee, C., \& Klenosky, B. (2003). The influence of push and pull factors at Korean national parks. Tourism Management, 24, 169-180. https://doi.org/10.1016/S0261-5177(02)00059-6

Kim, W., Ng, Y., \& Kim, Y. (2009). Influence of institutional DINSERV on customer satisfaction, return intention, and word-of-mouth. International Journal of Hospitality Management, 28(1), 10-17.

https://doi.org/10.1016/j.ijhm.2008.03.005 
Kim, H.J., Park, J., Kim, M.J., \& Ryu, K. (2013). Does perceived restaurant food healthiness matter? Its influence on value, satisfaction and revisit intentions in restaurant operations in South Korea. International Journal of Hospitality Management, 33, 397-405. https://doi.org/10.1016/j.ijhm.2012.10.010

Kim, Y.G., Eves, A., \& Scarles, C. (2009). Building a model of local food consumption on trips and holidays: A grounded theory approach. International Journal of Hospitality Management, 28, 423-431.

https://doi.org/10.1016/j.ijhm.2008.11.005

Kivela, J., \& Crotts, J.C. (2005). Gastronomy Tourism. Journal of Culinary Science \& Tourism, 4(2-3), 39-55. https://doi.org/10.1300/J385v04n02_03

Kivela, J., \& Crotts, J.C. (2006). Tourism \& gastronomy: Gastronomy's influence on how tourist experience a destination. Journal of Hospitality and Tourism Research, 30, 354-377. https://doi.org/10.1177/1096348006286797

Kline, C.S., Greenwood, J., \& Joyner, L. (2015). Exploring foodie segmentation. Journal of Tourism Insights, 6(1), 31-37. https://doi.org/10.9707/2328-0824.1049

Kotler, P. (1997). Marketing management: Analysis, planning, implementation and control. Upper Saddle River, NJ: PrenticeHall.

Kotler, P., Bowen, J., \& Makens, J. (2014). Marketing for Hospitality and Tourism (6th ed.). Boston: Pearson Education.

Kukanja, M., Omerzel, D.G., \& Kodrič, B. (2016). Ensuring restaurant quality and guests' loyalty: An integrative model based on marketing (7P) approach. Total Quality Management \& Business Excellence, 28(13-14), 1509-1525.

Lai, M. Y., Khoo-Lattimore, C., \& Wang, Y. (2017). Food and cuisine image in destination branding: Toward a conceptual model. Tourism and Hospitality Research, Online Press, 1-18. https://doi.org/10.1177/1467358417740763

Lee, T.H., Jan, F.H., Tseng, C.H., \& Lin, Y.F. (2018). Segmentation by recreation experience in island-based tourism: A case study of Taiwan's Liuqiu Island. Journal of Sustainable Tourism, 26(3), 362-378.

Leiper, N. (1990). Tourist attraction systems. Annals of tourism research, 17(3), 367-384.

https://doi.org/10.1016/0160-7383(90)90004-B

Lietz, P. (2010). Research into questionnaire design. International Journal of Market Research, 52(2), 249-272. https://doi.org/10.2501/S147078530920120X

Levitt, J.A., Zhang, P., DiPietro, R.B., \& Meng, F. (2017). Food tourist segmentation: Attitude, behavioral intentions and travel planning behaviour based on food involvement and motivation. International Journal of Hospitality \& Tourism Administration, Online Press, 1-27. https://doi.org/10.1080/15256480.2017.1359731

López-Guzmán, T., \& Sánchez-Cañizares, S. (2012). Culinary tourism in Córdoba (Spain). British Food Journal, 114(2), 168-179. https://doi.org/10.1108/00070701211202368

Mak, A.H.N., Lumbers, M., Eves, A., \& Chang, R.C.Y. (2012). Factors influencing tourist food consumption. International Journal of Hospitality Management, 31, 928-936. https://doi.org/10.1016/j.ijhm.2011.10.012

Marine-Roig, E., \& Anton Clavé, S. (2016). Perceived image specialisation in multiscalar tourism destinations. Journal of Destination Marketing \& Management, 5(3), 202-213. https://doi.org/10.1016/j.jdmm.2015.12.007

Manfreda, K.L., Bosnjak, M., Berzelak, J., Haas, I., Vehovar, V., \& Berzelak, N. (2008). Web surveys versus other survey modes: A meta-analysis comparing response rates. Journal of the Market Research Society, 50(1), 79. https://doi.org/10.1177/147078530805000107

Oppenheim, A.N. (1992). Questionnaire design, interviewing and attitude measurement. London: Continuum.

Pérez-Gálvez, J.C., López-Guzmán, T., Buiza, F.C., \& Medina-Viruel, M.J. (2017). Gastronomy as an element of attraction in a tourist destination: the case of Lima, Peru. Journal of Ethnic Foods. 4, 254-261.

https://doi.org/10.1016/j.jef.2017.11.002 
Roseman, M.G. (2006). Changing times: consumers choices of ethnic foods when eating at restaurants. Journal of Hospitality \&Leisure Marketing, 4(4), 5-32. https://doi.org/10.1300/J150v14n04_02

Sánchez-Cañizares, S.M., \& López-Guzmán, T. (2012). Gastronomy as a tourism resource: profile of the culinary tourist. Current Issues in Tourism, 15(3), 229-245. https://doi.org/10.1080/13683500.2011.589895

Sengel, T., Karagoz, A., Cetin, G., Dincer, F.I., Ertugral, S.M., \& Balık, M. (2015). Tourists' approach to local food. Procedia-Social and Behavioral Sciences, 195, 429-437. https://doi.org/10.1016/j.sbspro.2015.06.485

Seongseop, S.K., Choe, J.Y., \& Lee, A. (2016). Efforts to globalize a national food: Market segmentation by reasons for ethnic food preferences. International Journal of Contemporary Hospitality Management, 28(10), 2310-2330. https://doi.org/10.1108/IJCHM-03-2015-0151

Smith, S.L.J. (1994). The tourism product. Annals of Tourism Research, 21, 582-595. https://doi.org/10.1016/01607383(94)90121-X

Srihadi, T.F., Sukandar, D., \& Soehadi, A.W. (2016). Segmentation of the tourism market for Jakarta: Classification of foreign visitors' lifestyle typologies. Tourism Management Perspectives, 19, 32-39. https://doi.org/10.1016/j.tmp.2016.03.005

Srivastava, R.K. (2015). How differing demographic factors impact consumers' loyalty towards national or international fast food chains: A comparative study in emerging markets. British Food Journal, 117(4), 1354-1376. https://doi.org/10.1108/BFJ-07-2014-0230

Tan, A.Y. \& Lo, A.S. (2008). A benefit-based approach to market segmentation: a case study of an American specialty coffeehouse chain in Hong Kong. Journal of Hospitality \& Tourism Research, 32(3), 342-362. https://doi.org/10.1177/1096348008317388

The NPD Group (2017). El Mercado de restauraciónen 2016. CREST Consumidores. Available at: https://www.npdgroup.es (Accessed: 04/06/2017)

Thompson, M., \& Prideaux, B. (2009). Developing a food and wine segmentation and classifying destinations on the basis of their food and wine sectors. Advances in Hospitality and Leisure, 5, 163-183.

https://doi.org/10.1108/S1745-3542(2009)0000005013

Tsai, C.T. (2016). Memorable tourist experiences and place attachment when consuming local food. International Journal of Tourism Research, 18, 536-548. https://doi.org/10.1002/jtr.2070

Tse, P., \& Crotts, J.C. (2005). Antecedents of novelty seeking: international visitors' propensity to experiment across Hong Kong's culinary traditions. Tourism Management, 26(6), 965-968.

https://doi.org/10.1016/j.tourman.2004.07.002

Tuma, M.N., Decker, R., \& Scholz, S.W. (2011). A survey of the challenges and pitfalls of cluster analysis application in market segmentation. International Journal of Market Research, 53(3), 391-414. https://doi.org/10.2501/IJMR-53-3-391-414

UNWTO (1988). Glossary of Tourism Terms. Retrieved from: http://www2.unwto.org/sites/all/files/ (Accessed March 24th, 2018).

UNWTO (2017). Second Global Report on Gastronomy Tourism. Affiliate Members Reports, 16. Retrieved from: http://cf.cdn.unwto.org/sites/all/files/pdf/gastronomy report web.pdf (Accessed January24th, 2018).

Wadolowska, L., Babicz-Zelinska, E., \& Czarnocinska, J. (2008). Food choice models and their relation with food preferences and eating frequency in the polish population. Food Policy, 33, 122-134.

https://doi.org/10.1016/j.foodpol.2007.08.001

Wall, E.A., \& Berry, L.L. (2007). The combined effects of the physical environment and employee behavior on customer perception of restaurant service quality. Cornell Hotel and Restaurant Administration Quarterly, 48(1), 59-69. https://doi.org/10.1177/0010880406297246 
Wycherleya, A., McCarthy, M., \& Cowan, C. (2008). Specialty food orientation of food related lifestyle (FRL) segments in Great Britain. Food Quality and Preference, 19(5), 498-510.

https://doi.org/10.1016/j.foodqual.2008.02.006

Yang, W., \& Mattila, A. (2017). The Impact of Status Seeking on Consumers' Word of Mouth and Product Preference: A Comparison Between Luxury Hospitality Services and Luxury Goods. Journal of Hospitality \& Tourism Research, 41(1), 3-22. https://doi.org/10.1177/1096348013515920

Yuksel, A., \& Yuksel, F. (2003). Measurement of tourist satisfaction with restaurant services: A segment-based approach. Journal of Vacation Marketing, 9(1), 52-68. https://doi.org/10.1177/135676670200900104

Yuksel, A., Yuksel, F., \& Bilim, Y. (2010). Destination attachment: Effects on customer satisfaction and cognitive, affective and conative loyalty. Tourism Management, 31(2), 274-284. https://doi.org/10.1016/j.tourman.2009.03.007

\section{Annex I. Questionnaire in original language}

1. En cuántos restaurantes diferentes con estrella Michelin españoles ha comido o cenado en los últimos dos años

- Cuántos restaurantes con una estrella

- Cuántos restaurantes con dos estrellas

- Cuántos restaurantes con tres estrellas

- Ninguno: abandonar la encuesta

2. Seleccione el restaurante escogido (lista de restaurantes)

3. ¿Cómo conoció el restaurante escogido? (Marque tantas opciones como corresponda)

- Soy cliente habitual

- Me lo recomendaron

- Publicidad a nivel nacional por televisión

- Prensa

- Folletos turísticos

- Web del establecimiento

- Prensa especializada (revistas gastronómicas)

- Guía Michelin

- Web del destino turístico donde se encuentra el restaurante

- Buscadores Internet

- Web del establecimiento

- Redes sociales

- Blogs

- Oficina de información Turística

- Familiares o amigos

- Fue un regalo

- Otros (especifique):

4. Una vez ya conocía el restaurante. ¿Buscó información del restaurante estrella Michelin antes de realizar la reserva? En caso afirmativo, ¿a través de qué medios? (Marque tantas opciones como corresponda)

- No, no busqué información

- Web del establecimiento 
- Prensa especializada (revistas gastronómicas)

- Guía Michelin

- Web del destino turístico donde se encuentra el restaurante

- Buscadores Internet

- Web del establecimiento

- Redes Sociales

- Blogs

- Oficina de información Turística

- Familiares y amigos

- Otros

- (Especifique):

5. ¿Entró en la web del restaurante Michelin, antes, durante o después de visitarlo?

- $\quad$ Sí

- No

6. En la web del restaurante del restaurante x consultó: (Marque tantas opciones como corresponda)

- La localización

- La carta

- Los horarios

- Proceso para realizar la reserva

- Saber si disponía de parking

- Información sobre los eventos que realizan

- Información de servicio de Catering

- Información sobre cursos de cocina

- Información sobre promociones

- Como hacerme la tarjeta de fidelización/ pasaporte gastronómico

- Traducir a otro idioma

- Entré en la web y no encontré la información que buscaba sobre

- Otros(especifique):

7. Participó de forma activa en la web del restaurante x: (Marque tantas opciones como corresponda)

- Sí, rellené un cuestionario

- Sí, participé en fórums

- Sí, participé en chats

- Sí, me suscribí al newsletter

- Sí, me instalé la App

- Sí, a través de las redes sociales

- Otros(especifique)

- No, no participé de forma activa en la web 
8. En la web del restaurante estrella Michelin, consultó aspectos no relacionados con el restaurante como (Marque tantas opciones como corresponda)

- Informarme de los recursos turísticos de la zona

- Consultar el clima de la zona

- Buscar alojamiento

- Informarme sobre la oferta de actividades de la zona

- Links a otras actividades

- Entré en la web y no encontré la información que buscaba sobre

- Otros(especifique):

9. ¿Cómo realizó la reserva en el restaurante estrella Michelin?

- No, realicé reserva

- A través de la web del restaurante

- Por teléfono directamente con el establecimiento

- Vía correo electrónico

- A través de proveedores(empresas de bebidas, comida, bodegas etc.)

- A través de agencias de viajes físicas

- A través de una caja regalo (Smart box, Rusticae, etc)

- A través de portales de reservas (Atrápalo, Tenedor, etc)

- Fue una comida de empresa yo no realicé la reserva

- Otra persona realizó la reserva

- Otros (especifique):

10. ¿Cuantas personas contándose usted disfrutaron de la comida o cena en el restaurante Michelin que ha seleccionado?

11. ¿Quiénes conformaron el grupo en el momento de la comida o cena en el restaurante estrella Michelin? (Marque tantas opciones como corresponda)

- Pareja

- Familiares

- Amigos

- Compañeros de trabajo

- Otros (especifique):

12. ¿Compartió contenido en las redes sociales sobre la comida o cena del restaurante estrella Michelin?

- Sí, como suelo hacer siempre

- Sí, mucho más de lo habitual, aproveche la ocasión para compartir más cosas de lo que suelo hacer habitualmente

- Sí, pero menos de lo habitual

- No, aunque suelo conectarme en general

- No, no suelo conectarme en general 
13. ¿Qué tipo de contenido compartió referente a la experiencia en el restaurante? (Marque tantas opciones como corresponda)

- No compartí contenido

- Fotos

- Videos

- Comentarios

- Post en blog propio

- Otros (especifique):

14. ¿En qué red o redes sociales compartió contenido? (Marque tantas opciones como corresponda)

- WhatsApp

- Facebook

- Twitter

- Tuenti

- Google+

- Instagram

- Pinterest

- LinkedIn

- Youtube

- MySpace

- Foursquare

- Tumblr

- Spotify

- Badoo

- Otros (especifique):

15. Después de visitar el restaurante, ¿¿valoró el restaurante estrella Michelin en alguna red social?

- No, no realice ninguna valoración

- Sí, realice una valoración positiva

- Sí realice una valoración negativa

- Sí, realice una valoración neutra

- Otro(especifique):

16. En caso de dejar opiniones sobre el restaurante estrella Michelin, ¿en qué portal lo efectuó? (Marque tantas opciones como corresponda)

- TripAdvisor

- Foros gastronómicos

- Foros generales

- En el blog o las redes sociales del restaurante

- En mi propio blog

- En mis redes sociales

- Otro(especifique): 
17. A que distancia se encuentra el restaurante estrella Michelin de su residencia habitual.

- En la misma ciudad o alrededores

- Entre 10-100km

- Entre 50-100km

- Entre 100-300km

- Entre 300-600km Más de 200km

- Entre 600-1000km Más de 500km

- Más de $1000 \mathrm{~km}$

18. De las afirmaciones siguientes cual fue la razón principal por la que visitó el restaurante con estrella Michelin

- Visitar el destino fue el motivo principal y el restaurante fue el secundario

- El restaurante fue el motivo principal y el destino fue el secundario

- Tanto el destino como el restaurante fueron los motivos principales

- El restaurante en sí fue el único motivo

- Otros (especifique):

19. ¿Cuáles fueron los principales motivos por los que se desplazó al destino? Marque las opciones que usted considere máximo 4 por orden de importancia (señalando 1 como el más importante y 4 el de menor importancia).

- El gusto por la gastronomía

- Conocer la zona visitar el paisaje, lugares de interés

- Visitar recursos turísticos, museos, monumentos

- Descansar y desconectar

- Conocer los productos de la zona

- Trabajo/Negocios

- Fue un Regalo

- Evento, Festival, fiestas locales

- Compras

- Practicar algún deporte

- Visitar familiares y amigos

- No sabe/no contesta

20. Si no estuviera el restaurante Michelin al que fue, se hubiera desplazado al destino

- Sí, me hubiera desplazado para conocer ese destino

- No, no me hubiera desplazado para conocer ese destino

- Otro (especifique):

21. Usted asociaba la ciudad o localidad donde se ubica el restaurante Estrella Michelin con el restaurante o el cocinero? Por ejemplo

Rosas: Restaurante Bullí, cocinero Ferràn Adrià,

San Pol: Restaurante San Pau; cocinera Carmen Ruscalleda

Girona: Restaurante Celler Can Roca; Cocineros hermanos Roca 
- Sí, cuando alguien nombra la ciudad/localidad o pienso en esa ciudad/localidad rápidamente me viene a la mente el Restaurante o el cocinero/a o chef donde estuvimos

- No, no lo asocio al restaurante ni al cocinero/a

- Otro (especifique):

22. ¿Se informó antes de realizar el viaje sobre las posibles actividades para realizar o lugares para visitar en la zona/ localidad donde se encuentra el Restaurante que visitó (Marque tantas opciones como corresponda)

- No, no busqué información

- Sí, a través de web del establecimiento restaurante Michelin

- Web de información turística

- Buscadores (Google)

- Redes sociales

- Blogs

- Otros (especifique):

23. ¿Qué tipo de actividad/es realizó durante su desplazamiento o viaje en el destino? (Marque tantas opciones como corresponda)

- Actividades de tipo gastronómico (comidas en restaurantes, jornadas gastronómicas, ferias gastronómicas...)

- Actividades de tipo enológico (visitar bodegas, viñedos, catas, etc.)

- Turismo cultural y de ciudad (monumentos, museos etc.)

- Turismo de aventura (deportes acuáticos, senderismo, BTT, etc.)

- Turismo de salud (termas, spa)

- Turismo de negocios

- Turismo religioso

- Sol y playa

- Turismo de nieve

- Visita a familiares y amigos

- Estudios

- Ecoturismo (parques nacionales, montañas, ríos etc.)

- Visitar Parque temático

- Turismo de ocio nocturno

- Turismo náutico

- Ninguna actividad

- Otra (especifique):

24. ¿Qué duración tuvo la estancia en el destino/localidad donde se encuentra el restaurante estrella Michelin? (entendiendo por destino como máximo 30040 minutos)

- De menos de $24 \mathrm{~h}$

- 1 noche

- 2 noches

- 3 noches

- 4 noches 
- 5 noches

- 6 noches

- 7 noches

- $\quad+$ de 7 noches

25. ¿Qué tipo de Alojamiento seleccionó? (Marque tantas opciones como corresponda)

- En el mismo establecimiento donde se encuentra el restaurante

- Hotel/Apartahotel *

- Hotel/Apartahotel **

- Hotel/ Apartahotel ***

- Hotel/Apartahotel ****

- Hotel/ Apartahotel *****

- Vivienda alquilada

- Vivienda de propiedad

- Casa rural

- Hostal

- Vivienda de familiares y amigos

- Otros (especifique)

26. ¿Cuantas comidas y/o cenas realizó fuera del alojamiento?

$$
\begin{array}{llllllllll}
1 & 2 & 3 & 4 & 5 & 6 & 7 & 8 & 9 & 100+
\end{array}
$$

27. La opinión que tiene respecto a su experiencia en el destino: alojamiento, actividades (1 totalmente desacuerdo, 5 totalmente de acuerdo)

- He disfrutado mucho

- Mi elección fue acertada

- $\quad$ Estoy satisfecho con mi experiencia

- $\quad$ Es exactamente lo que yo necesitaba

28. La opinión que tiene respecto a su experiencia gastronómica en el restaurante x (1 totalmente desacuerdo, 5 totalmente de acuerdo)

- He disfrutado mucho

- Mi elección fue acertada

- Estoy satisfecho con mi experiencia

- $\quad$ Es exactamente lo que yo necesitaba

29. Valore los siguientes Atributos relacionados con la gastronomía que a usted le han influenciado a la hora de visitar un restaurante estrella Michelin (1 no me han influenciado nada, 5 si me han influenciado mucho)

- Aprender de gastronomía y cocina

- $\quad$ El gusto por el vino

- Probar nuevas texturas, sabores y platos diferentes

- Conocer nuevas formas de elaboración, cocción, presentación, etc. 
- La calidad de las materias primas utilizadas para la elaboración de los platos

- Conocer los productos de la zona

30. Valore los siguientes Atributos personales que a usted le han influenciado a la hora de visitar un restaurante estrella Michelin (1 no me han influenciado nada, 5 si me han influenciado mucho)

- El estatus que me proporciona

- Visitar restaurantes Michelin me ayuda a ser aceptado por otras personas

- Disfrutar de conocer al chef (cocinero)

- Visitar restaurantes Michelin impresiona a la gente

- Poder contarlo más tarde a mis familiares y amigos

- Descansar y desconectar

- Me lo han regalado

- Me hace feliz

- Las buenas experiencias en los restaurantes Michelin perduran en mi memoria por un periodo largo de tiempo

- Me gusta comer bien y frecuento los restaurantes Michelin a menudo

31. Valore los siguientes Atributos relacionados con el establecimiento que a usted le han influenciado a la hora de visitar un restaurante estrella Michelin (1 no me han influenciado nada, 5 si me han influenciado mucho)

- Decoración del establecimiento

- El servicio tan esmerado que prestan en este tipo de restaurantes

- Posibilidad de visitar las instalaciones, cocina, Bodega, etc.

- La atención al cliente

- Ubicación (emplazamiento, vistas etc.)

- Tienda gourmet

- Parking

32. La probabilidad que concede a las siguientes intenciones es de (1 muy poco probable, 5 muy probable)

- Intentaré volver a este restaurante en los próximos años

- Tras mi experiencia actual, pienso que visitaré de Nuevo la zona

- Animaré a mis familiares y amigos a que visiten el restaurante

- Animaré a mis familiares y amigos a que visiten la zona

- Recomendaría este restaurante si alguien me pidiera consejo

- Recomendaría esta zona si alguien me pidiera consejo

33. ¿Cuántos viajes o escapadas fuera de su lugar de residencia con alojamiento sueles hacer de media al año??
$0 \quad 1$
23
4
6
7
$8910 \mathrm{o}+$

\section{Preguntas sociodemográficas}

34. Indique su sexo

- Mujer

- Hombre 
35. ¿Cuál es su edad?

- Menos de 15 años

- De 15 a 24 años

- De 25 a 34 años

- De 35 a 44 años

- De 45 a 54 años

- De 55 a 64 años

- De 65 a 74 años

- De 75 o más

36. ¿Cuál es su nivel de estudios?

- Sin estudios

- Educación primaria

- Estudios hasta los 13 - 14 años

- Estudios hasta los 15 - 16 años

- Estudios hasta los 17 - 19 años

- Educación universitaria

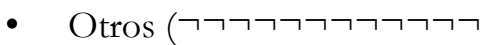

37. Ocupación (marque tantas opciones como corresponda)

- Trabajador

- Estudiante

- Ama de casa

- Parado

- Jubilado

- Otros

38. ¿Cuál es su profesión actual?

- Profesional liberal

- Empresario/a con asalariados

- Mando superior

- Mando intermedio

- Autónomo

- Administrativo

- Técnico especialista

- Profesional por cuenta ajena(medico, profesor)

- Obrero cualificado

- Obrero no cualificado

- Otros(especificar) 
39. ¿Nos puede indicar los ingresos mensuales netos de su hogar por todos los conceptos?

- Menos de 500 euros

- De 500 a 1000 euros

- De 1.001 a 1.500 euros

- De 1.501 a 2.000 euros

- De 2.001 a 2.500 euros

- De 2.501 a 3.000 euros

- De 3.001 a 5.000 euros

- De 5.001 a 7.000 euros

- De 7.001 a 9000 euros

- Más de 9000

40. En qué país / comunidad autónoma reside habitualmente

PAÍS/ CCAA (desplegable)

Intangible Capital, 2018 (www.intangiblecapital.org)

\section{(c) (i) (8)}

Article's contents are provided on an Attribution-Non Commercial 4.0 Creative commons International License. Readers are allowed to copy, distribute and communicate article's contents, provided the author's and Intangible Capital's names are included. It must not be used for commercial purposes. To see the complete license contents, please visit https://creativecommons.org/licenses/by-nc/4.0/. 